\title{
Genetics of Systemic Sclerosis: An Update
}

\author{
Jasper C. A. Broen • Marieke J. H. Coenen • \\ Timothy R. D. J. Radstake
}

Published online: 19 November 2011

(C) The Author(s) 2011. This article is published with open access at Springerlink.com

\begin{abstract}
Systemic sclerosis (SSc) is an autoimmune disease characterized by vasculopathy, immune cell activation, and fibrosis of the skin and internal organs. Over the past few years, a role for genetics in the susceptibility for SSc has been established. This review aims to provide an update on the progress made in the past year or so within the field of SSc genetics research. This year has been of particular interest due to the publication of a large genome-wide association study, further investigations into gene-gene interactions, and the tendency to validate genetic results in functional models.
\end{abstract}

Keywords Systemic sclerosis · Genetics · Polymorphisms · Family studies · Genome-wide association studies

\section{Introduction}

Systemic sclerosis (SSc) is a multifaceted autoimmune disease. Its main manifestations are vasculopathy, immune activation, and ultimately extensive fibrosis of the skin and internal organs [1]. Until recently, the precise pathogenesis had not been elucidated, despite the growing interest and efforts from the scientific community in unraveling the factors involved in SSc susceptibility. Over the years, it has

J. C. A. Broen · T. R. D. J. Radstake ( $₫)$

Department of Rheumatology,

Radboud University Nijmegen Medical Centre,

Geert Grooteplein 8,

6500 HB Nijmegen, The Netherlands

e-mail: t.radstake@reuma.umcn.nl

M. J. H. Coenen

Department of Human Genetics,

Radboud University Medical Centre,

Nijmegen, The Netherlands been suggested that environmental as well as genetic risk factors predispose individuals to the onset of SSc [2, 3]. Environmental factors are likely to play a role in triggering disease because genetics does not provide a full justification for the development of SSc. However, reports on predisposing environmental factors are ambiguous, and meta-analyses are severely hindered by differences in the methodologies used for exposure measurement by individual studies [4], which unfortunately leaves a convincing environmental risk factor to be discovered. Despite the difficulties involved with composing large, clinically well-defined cohorts, genetic research was able to discover multiple genetic risk factors that have been replicated or challenged by other studies. Many small and underpowered studies scrutinizing genetic risk factors were published in an earlier period, but thanks to the remarkable evolution of genetic research, SSc genetic cohorts and the genetic analyses performed became more comprehensive. Extensive reviews of these small studies and other findings in the field of genetic research throughout history have been published recently [5]. The aim of this review is to provide an update on the key findings emerging from studies from the past year that have explored the genetic background of SSc.

\section{Family Studies}

Although SSc is not inherited in a mendelian fashion, the highest risk factor for developing SSc today remains having a sibling (15- to 19-fold increase) or other first-degree relative (13- to 15-fold increase) with SSc. It must be noted that the relative risk (RR) of developing SSc remains rather low: $1.6 \%$ in families versus $0.026 \%$ in the general population [6, 7]. In 2010, these findings were further substantiated by a study investigating the heritability of SSc 
in relation to Raynaud's phenomenon (RP), other autoimmune disease (AID), and fibrotic interstitial lung disease [8]. This study utilized a very powerful genealogic resource, the Utah Population Database, which contains both family structure data and medical records from more than 7 million individuals. The genetic structure of Utah residents is most similar to descendants from Northern Europe in that very low inbreeding rates are present. The cohort harbored 1,316 unique SSc patients, 1,037 of whom had a child and/or a parent and hence could be included in the study. For each SSc patient, 10 age-, gender-, and place of birth-matched healthy controls were randomly selected. From these 1,037 individuals, 50 families were identified that had a significantly larger than expected number of SSc cases. In these families, the RR ranged from 3.07 (95\% CI, $1.25-7.57)$ in first-degree relatives to 2.14 (95\% CI, 1.16$3.95)$ in third-degree relatives. In fourth-degree relatives, no significantly increased risk was present. An additional prerequisite of this study was that it included the heritability of RP among relatives of individuals with SSc. The study found a significant increase in RP risk in first- and seconddegree relatives (RR, 6.38 [95\% CI, 3.44-11.83] and 2.39 [95\% CI, 1.21-4.74], respectively). The results concerning fibrotic disease heritability were somewhat less straightforward, as first- to fourth-degree relatives all had a significantly increased risk of developing interstitial lung disease, except the second-degree relatives. The authors did not provide a clear explanation for this observation but stated that the analysis may be limited by the selection of only interstitial lung disease as an outcome for inheritance of fibrosing disease, excluding, for instance, morphea and biliary cirrhosis. The third result presented in this study-the increased prevalence of other AIDs in families with SSc - matches the results of another study published in 2010 [9]. This study described a markedly increased prevalence of systemic lupus erythematosus (SLE) in North American families from 1,071 SSc probands (OR, 16.98 [95\% CI, 1.02-227.82]). To a lesser extent, hypothyroidism (OR, 2.51 [95\% CI, 1.464.62]) and hyperthyroidism (OR, 2.76 [95\% CI, 1.16-7.97]) were found to have an increased prevalence in these families. The Achilles heel of this kind of study is the validation of family-derived data. The study conducted in Utah based the identification of cases on billing codes. Unfortunately, the data used were de-identified, so no independent validation could be carried out. In addition, the authors noted that not all SSc patients had a record of RP, which is generally considered to be almost universally present in SSc. Cases in the second study were well-ascertained by chart review or interviews of all first-degree relatives with reported AID by the same rheumatologist. Intriguingly, a study comparing $987 \mathrm{SSc}$ cases with their 3,088 unaffected siblings found that the risk of developing SSc increased with increasing order of birth and number of pregnancies, suggesting that immune development very soon after birth or during pregnancy plays a role in SSc development [10•]. These findings might be the start of the unveiling of an apparent role for (epigenetic) imprinting and may wipe the dust from older studies describing a role for microchimerism in SSc [11].

\section{Candidate Gene Studies}

Over the past few years, several single nucleotide polymorphisms (SNPs) have been found to be enriched in patients with SSc or its clinical phenotypes compared with healthy controls. The SNPs were usually selected based on their locus in a gene likely to be involved in SSc pathogenesis, or when the SNP already posed a risk to another AID. Using these strategies, several novel genetic risk factors were identified. Herein we review new insights into the role of established candidate genes and describe novel associations. We focus on studies of sufficient size and power or findings that are, in our opinion, of special interest. In the last paragraph of this section, we briefly highlight some welldesigned studies with negative results, which fortunately seem to be accepted for publication more frequently in recent years, counterbalancing positive publication bias. Table 1 displays the effect sizes and summarizes the results of the studies described below.

\section{STAT4}

After the discovery that signal transducer and activator of transcription 4 (STAT4) polymorphisms play a role in rheumatoid arthritis (RA) and SLE susceptibility [12], a role for this gene in SSc susceptibility was found as well. An initial study in 1,317 SSc patients and 3,113 healthy controls found the STAT4 rs7574865 T allele to be associated with limited cutaneous SSc (lcSSc), but not with diffuse cutaneous SSc (dcSSC) [13]. The same association was substantiated in a Japanese cohort [14]. Subsequently, two other studies corroborated these results and strongly implicated STAT4 in SSc susceptibility $[15,16]$. Last year, these results prompted a combined European effort to investigate the functional role of the STAT4 gene in mice. Both STAT4-deficient wild-type mice were injected with bleomycin. STAT4 knockout mice had a decreased T-cell activation, proliferation, and cytokine release, which led to less fibrosis. Of interest, STAT4-deficient Tsk1 mice (a wellrecognized murine SSc model) did not have a more severe fibrotic phenotype. From these observations, the authors drew the conclusion that STAT4 is intricately involved in fibrosis and activation of fibroblasts. However, it must be noted that STAT4 is a T-helper type 1 (Th1) promoter as well; therefore, a more straightforward explanation might be that STAT4-deficient mice have fewer Th1 circulating cells and 
Table 1 Newly described non-HLA susceptibility genes for SSc and its clinical phenotypes

\begin{tabular}{|c|c|c|c|c|c|c|}
\hline Gene & SNP (associated allele/genotype) & Association & Population & Size (tested phenotype/HC) & OR $(95 \% \mathrm{CI})$ & Reference \\
\hline \multirow[t]{17}{*}{ TNFSF4 } & \multirow[t]{2}{*}{ rs2205960 (T allele) } & $\mathrm{SSc}$ & US & $1,059 / 698$ & $1.2(1.1-1.5)$ & [19] \\
\hline & & $\mathrm{ATA}^{+}$ & US & $174 / 698$ & $1.4(1.1-1.9)$ & [19] \\
\hline & \multirow[t]{6}{*}{ rs1234314 (G allele) } & $\mathrm{SSc}$ & US & $1,059 / 698$ & $1.2(1.04-1.4)$ & [19] \\
\hline & & $\mathrm{ACA}^{+}$ & US & $300 / 698$ & $1.3(1.1-1.6)$ & [19] \\
\hline & & $\mathrm{ATA}^{+}$ & US & $174 / 698$ & $1.3(1.02-1.7)$ & [19] \\
\hline & & $\mathrm{SSc}$ & European & $2,856 / 2,920$ & $1.15(1.02-1.31)$ & {$[20]$} \\
\hline & & $1 \mathrm{cSSc}$ & European & $1,608 / 2,920$ & $1.22(1.07-1.38)$ & {$[20]$} \\
\hline & & $\mathrm{ACA}^{+}$ & European & $828 / 2,920$ & $1.23(1.10-1.37)$ & {$[20]$} \\
\hline & \multirow[t]{4}{*}{ rs844648 (A allele) } & $\mathrm{SSc}$ & US & $1,059 / 698$ & $0.8(0.7-0.97)$ & [19] \\
\hline & & $\mathrm{ATA}^{+}$ & US & $193 / 698$ & $1.4(1.1-1.8)$ & [19] \\
\hline & & $\mathrm{lcSSc}$ & European & $1,673 / 2,977$ & $1.1(1.01-1.20)$ & {$[20]$} \\
\hline & & $\mathrm{ACA}^{+}$ & European & $860 / 2,977$ & $1.12(1.01-1.25)$ & {$[20]$} \\
\hline & \multirow[t]{2}{*}{ rs844644 (A allele) } & lcSSc & European & $1,653 / 2,946$ & $0.91(0.83-0.99)$ & {$[20]$} \\
\hline & & $\mathrm{ACA}^{+}$ & European & $856 / 2,912$ & $0.90(0.80-1.00)$ & {$[20]$} \\
\hline & \multirow[t]{3}{*}{ rs12039904 (T allele) } & $\mathrm{SSc}$ & European & $2,894 / 2,991$ & $1.18(1.08-1.29)$ & {$[20]$} \\
\hline & & lcSSc & European & $1,639 / 2,991$ & $1.20(1.09-1.33)$ & {$[20]$} \\
\hline & & $\mathrm{ACA}^{+}$ & European & $840 / 2,991$ & $1.22(1.07-1.38)$ & {$[20]$} \\
\hline \multirow[t]{7}{*}{$B L K$} & \multirow[t]{2}{*}{ rs2736340 (TT genotype) } & $\mathrm{SSc}$ & European and US & $1,639 / 1,416$ & $1.71(1.2-2.4)$ & {$[22]$} \\
\hline & & $\mathrm{ACA}^{+}$ & European and US & $510 / 1,416$ & $2.27(1.5-3.5)$ & [22] \\
\hline & \multirow[t]{2}{*}{ rs2736340 (CT genotype) } & $\mathrm{SSc}$ & European and US & $1,639 / 1,416$ & $1.31(1.1-1.5)$ & [22] \\
\hline & & $\mathrm{ACA}^{+}$ & European and US & $510 / 1,416$ & $1.6(1.2-2.0)$ & [22] \\
\hline & \multirow[t]{2}{*}{ rs13277113 (AA genotype) } & $\mathrm{SSc}$ & European and US & $1,639 / 1,416$ & $1.25(1.1-1.4)$ & [22] \\
\hline & & $\mathrm{ACA}^{+}$ & European and US & $510 / 1,416$ & $1.42(1.2-1.7)$ & [22] \\
\hline & rs13277113 (A allele) & $\mathrm{SSc}$ & Japanese & $309 / 769$ & $1.45(1.17-1.79)$ & {$[22]$} \\
\hline \multirow[t]{4}{*}{ TNFAIP 3} & \multirow[t]{4}{*}{ rs5029939 (T allele) } & $\mathrm{SSc}$ & European & $1,667 / 1,318$ & $2.08(1.59-2.72)$ & {$[25]$} \\
\hline & & $\mathrm{dcSSc}$ & European & $523 / 1,318$ & $2.71(1.94-3.79)$ & {$[25]$} \\
\hline & & FA & European & $532 / 1,318$ & $2.26(1.61-3.17)$ & {$[25]$} \\
\hline & & PAH & European & $119 / 1,318$ & $3.11(1.86-5.17)$ & {$[25]$} \\
\hline KCNA5 & rs10744676 (C allele) & PAH & European & $192 / 1,008$ & $0.36(0.21-0.63)$ & [27] \\
\hline \multirow[t]{2}{*}{ PTPN22 } & \multirow[t]{2}{*}{ rs2476601 (T allele) } & $\mathrm{SSc}$ & European and US & $3,422 / 3,638$ & $1.15(1.03-1.28)$ & {$[32]$} \\
\hline & & $\mathrm{ACA}^{+}$ & European and US & $1,376 / 4,126$ & $1.22(1.05-1.42)$ & [32] \\
\hline \multirow[t]{2}{*}{$N L R P 1$} & \multirow[t]{2}{*}{ rs8182352 (C allele) } & FA & European & $674 / 1,587$ & $1.19(1.05-1.36)$ & {$[34]$} \\
\hline & & $\mathrm{ATA}^{+}$ & European & $536 / 1,587$ & $1.23(1.07-1.41)$ & [34] \\
\hline$H G F$ & $H G F-1652$ (TT genotype) & ESLD & Japanese & $30 / 268$ & $8.1(2.5-26.0)$ & {$[36 \bullet]$} \\
\hline \multirow[t]{4}{*}{$C D 226$} & rs763361 ( $\mathrm{T}$ allele $)$ & $\mathrm{SSc}$ & European & $1,990 / 1,642$ & $1.22(1.10-1.34)$ & [39] \\
\hline & \multirow[t]{3}{*}{ rs763361 (TT genotype) } & $\mathrm{dcSSc}$ & European & $600 / 1,642$ & $1.86(1.42-2.43)$ & [39] \\
\hline & & FA & European & $662 / 1,642$ & $1.82(1.38-2.40)$ & [39] \\
\hline & & $\mathrm{ATA}^{+}$ & European & $553 / 1,642$ & $1.61(1.25-2.08)$ & [39] \\
\hline \multirow[t]{5}{*}{$C D 247$} & \multirow[t]{5}{*}{ rs2056626 (G allele) } & $\mathrm{SSc}$ & European and US & $5,049 / 9,740$ & $0.85(0.81-0.89)$ & {$[47 \cdot]$} \\
\hline & & $\mathrm{SSc}$ & French & $1,031 / 1,014$ & $0.78(0.68-0.88)$ & [49] \\
\hline & & $\mathrm{dcSSc}$ & French & $308 / 1,014$ & $0.79(0.65-0.95)$ & [49] \\
\hline & & $1 \mathrm{cSSc}$ & French & $643 / 1,014$ & $0.79(0.69-0.92)$ & [49] \\
\hline & & FA & French & $346 / 1,014$ & $0.78(0.65-0.93)$ & [49] \\
\hline IRF8 & rs11642873 (A allele) & $1 \mathrm{cSSc}$ & European and US & $3,360 / 10,143$ & $0.75(0.69-0.81)$ & {$[50 \bullet]$} \\
\hline GRB10 & rs12540874 (A allele) & $1 \mathrm{cSSc}$ & European and US & $3,360 / 10,143$ & $1.15(1.09-1.22)$ & {$[50 \bullet]$} \\
\hline SOX5 & rs11047102 (C allele) & $\mathrm{ACA}^{+}$ & European and US & $1,791 / 10,143$ & $1.36(1.21-1.52)$ & {$[50 \bullet]$} \\
\hline TNIPI & rs2233287 (A allele) & $\mathrm{SSc}$ & European & $2,246 / 4,684$ & $1.31(1.15-1.43)$ & [51] \\
\hline RHOB & rs13021401 (T allele) & $\mathrm{SSc}$ & European & $2,246 / 4,684$ & $1.21(1.12-1.31)$ & {$[51]$} \\
\hline
\end{tabular}

$A C A$ anticentromere antibody; $A T A$ antitopoisomerase antibody; $d c S S c$ diffuse cutaneous systemic sclerosis; $E S L D$ end-stage lung disease; FA fibrosing alveolitis; $H C$ healthy controls; lcSSc limited cutaneous systemic sclerosis; $P A H$ pulmonary arterial hypertension; $S N P$ single nucleotide polymorphism $S S c$ systemic sclerosis 
consequently cannot mount the same response as STAT4 wild-type mice - something the authors did not address [17•]. Consequently, these results might be coming from an overall impaired immune system rather than specifically less fibrotic potential, as the authors state. In addition, SSc patients carry an SNP in the gene that probably has a less pronounced effect on the gene function than a complete deletion of the gene, complicating translation of findings in mice to human patients. More subtle approaches, such as making use of immune cells from carriers of this particular variant, are welcome to better gauge the precise implication of this polymorphism in SSc.

\section{OX40L}

Tumor necrosis factor superfamily-4 (TNFSF4 or OX40 ligand $[O X 40 L])$ is the natural ligand of OX40, which is present on $\mathrm{T}$ cells and influences $\mathrm{T}$-cell survival and expansion. OX40L binding partner OX40 is more highly expressed in the serum of SSc patients than in healthy controls. Moreover, polymorphisms in this gene have been associated with SLE previously [18]. An initial American cohort consisting of 1,059 Caucasian SSc cases and 698 healthy controls found the rare variants of SNPs rs2205960, rs1234314, and rs844648 to be associated with SSc susceptibility. Additional analysis of clinical phenotypes demonstrated significant associations of $O X 40 \mathrm{~L}$ variants with $\mathrm{lcSSc}$ and dcSSC, as well as antitopoisomerase antibody (ATA) and anticentromere antibody (ACA) profiles [19]. These results were recently corroborated by a European effort investigating the influence of TNFSF4 polymorphisms in SSc susceptibility. This study found the most marked associations in patients with lcSSc and ACAs. In addition, this study identified novel OX40L haplotypes involved in SSc susceptibility [20].

\section{The FAM167A-BLK Region}

The FAM167A-BLK region, previously known as C8orf13$B L K$, has been associated with multiple immune diseases [21]. In 2010, two studies addressing two polymorphisms in this region, rs 13277113 and rs2736340, found an association with $\mathrm{lcSSc}$ and dcSSc. The $\mathrm{T}$ allelle of rs2736340 was associated with SSc in both a US and a Spanish case-control population [22]. Both variants were enriched in patients with ACAs and $\mathrm{lcSSc}$ in a combined analysis. A role for the rs13277113 variant in SSc was further substantiated by a Japanese study, which did not investigate rs2736340 [23]. Moreover, RNA expression profiling using peripheral blood elucidated significantly differentially expressed genes in the B-cell receptor-signaling pathways between patients with different genotypes [22].

\section{TNFAIP3}

Tumor necrosis factor- $\alpha$-induced protein 3 (TNFAIP3) is a cytoplasmic zinc finger protein that inhibits nuclear factor- $\mathrm{KB}$ activity and tumor necrosis factor-mediated programmed cell death. Polymorphisms in this gene have been repeatedly associated with AID susceptibility [24]. A European study investigated 3 SNPs in 1,018 French patients with SSc and 1,012 French Caucasian controls. The TNFAIP3 rs5029939 was found to be associated with SSc and subsequently replicated in a second set of 649 patients and 306 controls of German and Italian descent (OR, 2.08 [95\% CI, 1.59-2.72]). In addition, the strongest association of rs5029939 was observed for dcSSc (OR, 2.71 [95\% CI, 1.94-3.79]), fibrosing alveolitis (OR, 2.26 [95\% CI, 1.61-3.17]), and pulmonary arterial hypertension (PAH) (OR, 3.11 [95\% CI, 1.86-5.17]) [25].

\section{KCNA5}

Based on the observations of potassium voltage-gated channel, shaker-related subfamily, member 5 (KCNA5) polymorphisms contributing to idiopathic pulmonary hypertension, a study was initiated in $638 \mathrm{SSc}$ patients and 469 controls to determine whether $K C N A 5$ polymorphisms confer susceptibility to SSc and, more specifically, to PAH [26]. Four KCNA5 SNPs were genotyped, from which the rs10744676 variant was found to be associated with SSc (OR, 0.62 [95\% CI, 0.48-0.79]). In addition, this polymorphism influenced SSc-related PAH (OR, 0.31 [95\% CI, $0.13-0.71]$ ). Subsequently, the results were replicated in 938 SSc patients and 564 controls. The above association with $\mathrm{PAH}$ in SSc was replicated, but not the association with SSc overall. However, some care must be taken with interpretation of these results because this study did not only include patients diagnosed with $\mathrm{PAH}$ on the basis of right heart catheterization, but also included those with PAH based on isolated diffusing capacity of the lung for carbon monoxide less than $50 \%$ predicted, and with unexplained dyspnea [27].

\section{PTPN22}

Protein tyrosine phosphatase non-receptor 22 (PTPN22) has been found to be associated with a broad array of AIDs, including RA and SLE [28]. Although not fully conclusive, a role for the PTPN22 R620W polymorphism has been evaluated in SSc multiple times [29-31]. This year, a study was published again addressing the role of this variant but also the role of a novel described PTPN22 variant in SSc susceptibility. In total, 3,422 SSc patients and 3,638 healthy controls from 7 different ethnic cohorts were included in this study. The meta-analysis performed in these cohorts identified the rs2476601 $\mathrm{T}$ allele as a risk factor for SSc 
susceptibility (OR, 1.15 [95\% CI, 1.03-1.28]). Moreover, the rs $2476601 \mathrm{~T}$ allele was significantly associated with ACAs (OR, 1.22 [95\% CI, 1.05-1.42]). The study suggests that the PTPN22 R620W polymorphism influences SSc genetic susceptibility, whereas the novel R263Q genetic variant does not [32].

\section{$N L R P 1$}

Based on the idea that $\mathrm{T}$ cells are able to dampen the inflammasome through NLRP1 responses and the observation that NLRP1 variants were found to confer susceptibility to AIDs, an endeavor was initiated to investigate this gene in SSc [33]. This study focused on 5 polymorphisms in a discovery set composed of $870 \mathrm{SSc}$ patients and 962 controls and a German and Italian replication set consisting of 1,060 SSc patients and 625 controls. The discovery cohort revealed a significant association for the NLRP1 rs8182352 variant with both ATAs and fibrosing alveolitis. In the replication cohort, no association was detected in the German population. However, the association with ATAs was replicated in the Italian population. When a meta-analysis was performed considering an additive model for the rs8182352 SNP, the investigators found this variant to confer susceptibility to ATAs and fibrosing alveolitis under an additive model (OR, 1.23 [95\% CI, 1.07-1.41] and 1.19 [95\% CI, 1.05-1.35], respectively). In addition, logistic regression analysis showed an additive effect of IRF5 rs2004640, STAT4 rs7574865, and NLRP1 rs8182352 risk alleles on SSc-related fibrosing alveolitis [34]. Although the authors state that NLRP1 is a new genetic susceptibility factor for SSc-related pulmonary fibrosis and ATA-positive SSc, this study would benefit from an independent replication study. As the results coming from the replication cohort are not straightforward, it would be interesting to know the pooled results of the replication cohort.

\section{Hepatocyte Growth Factor}

Hepatocyte growth factor $(H G F)$ is an antifibrotic factor involved in regenerating damaged tissue by inhibiting fibrosis and promoting angiogenesis [35]. $H G F$ seems to be on the other side of the fibrotic mediator spectrum as transforming growth factor- $\beta$ and therefore might be involved in regulating fibrosis as observed in SSc. A recent Japanese study examined four SNPs within $H G F$ and its receptor c-met for a role in SSc or SSc clinical subset pathogenesis. The authors did not find a difference in the distribution of the alleles of $H G F$ or $c$-met SNPs between SSc patients and controls. Interestingly, they found the $H G F-1652$ TT genotype significantly more frequently in SSc patients with end-stage lung disease compared with patients without that disease $(41 \%$ vs $8 \%)$. This association was confirmed in a relatively small replication study consisting of $155 \mathrm{SSc}$ patients. Compensating for the relatively small replication cohort is a Kaplan-Meyer survival analysis showing that $H G F-1652$ TT carriers had a higher probability of developing end-stage lung disease in time than did carriers of the $\mathrm{CT}$ or $\mathrm{CC}$ genotype. In addition, the HGF promoter harboring the $H G F-1652 \mathrm{~T}$ allele displayed decreased transcriptional activity compared with the promoter carrying the $\mathrm{C}$ allele, which was investigated by a luciferase reporter assay. Electrophoretic mobility shift assays unveiled the presence of a potential negative transcriptional regulator specifically binding to the $H G F$ promoter and harboring the $H G F-1652 \mathrm{~T}$ allele [36•]. Despite its small size, this study is of particular interest because it describes a variant of the $H G F$ gene distinctively involved in the fibrosis observed in SSc and shapes out its functional relevance. Moreover, the results are analyzed and presented in a Kaplan-Meyer curve that points out clinical relevance more clearly than plain tables.

\section{$C D 226$}

CD226, encoding DNAX accessory molecule 1, is important in monocyte extravasation and was recently found to be a genetic risk factor for AID [37, 38]. This observation prompted investigation of a possible association of the CD226 rs763361 nonsynonymous polymorphism with SSc. To this purpose, a discovery cohort of $991 \mathrm{SSc}$ patients and 1,008 controls and a replication cohort of 999 SSc patients and 634 controls from European Caucasian descent were utilized. The CD226 rs763361 T allele was found to be associated with SSc in the discovery and the replication samples (OR, 1.22 [95\% CI, 1.10-1.34]). In addition, the CD226 TT risk genotype was associated with dcSSc (OR, 1.86 [95\% CI, 1.42-2.43]), ATAs (OR, $1.82[95 \% \mathrm{CI}$, $1.38-2.40]$ ), and fibrosing alveolitis (OR, 1.61 [95\% CI, $1.25-2.08])$. To investigate the functional relevance of the identified genetic risk factor, expression of CD226 was assessed on $\mathrm{CD}^{+}, \mathrm{CD}^{+}, \mathrm{CD}^{+}, \mathrm{CD} 6^{+}$, and natural killer $\mathrm{T}^{+}$cells obtained from 21 healthy donors genotyped for CD226, and rs763361 was measured. The polymorphism did not result in a significant change of CD226 expression among these different sets of T cells [39].

The results described above, together with previously described findings, might imply that the genetic background is exactly similar to that of other AIDs or the idiopathic form of the SSc complication. However, although it is undeniable that there is a large resemblance between the genetic backgrounds of AIDs, some recently published studies also point out genes previously associated with AID that are not associated with SSc. This was true for the SLE-associated genes CD89, FCGR2A, FCGR3A, ITGAM, ITGAX, and CD58 [40-42]. In addition, a 
polymorphism previously associated with idiopathic or familiar hypertension and situated in the SLC6A4 gene was not found to be associated with SSc-related PAH [43]. Finally, some potential genetic defects involved in SSc pathogenic events were discarded, including the $M M P 2$, $M M P 9$, and MMP14 genes [44]. These studies, if wellperformed and well-powered, are important because they carve out the differences between AIDs more explicitly.

\section{Genome-Wide Association Studies}

Before 2010, two genome-wide association studies (GWAS) were published addressing genetic susceptibility to SSc in a non-hypothesis-driven manner. Although very relevant at the time, they were premature considering the current standards for marker resolution and patient and control numbers. The first study utilized 400 markers and targeted 20 Choctaw patients with SSc and 76 matched controls [45]. The second (Korean) GWAS used an efficient number of 500,568 SNP markers but included only 137 SSc patients and 564 controls. Unfortunately, the identified risk factors for SSc were not replicated in a large US cohort. Noteworthy, SNPs in genes previously associated with SSc, including the aforementioned PTPN22, showed low $P$ values but failed to reach genome-wide significance [46]. In 2010, however, a large and robust GWAS was published. This study included 2,296 SSc patients and 5,171 healthy controls originating from The Netherlands, Germany, Spain, and the United States. Different sets of markers were used that ranged in density from 308,349-488,793 SNPs. This study adjusted for multiple testing by regarding the genome-wide significance threshold $\left(P \leq 5 \times 10^{-7}\right)$ as the limit for significance. The strongest association was observed at the 6p21 locus in the midst of the major histocompatibility complex region. At this region, rs6457617, situated in $H L A^{*} D Q B 1$, showed the strongest association. In addition, five non- $H L A$ loci showed genome-wide significance: TNPO3/IRF5 region in $7 \mathrm{q} 32$, STAT4 in 2q32, CD247 in 1q22-23, CDH7 in $18 \mathrm{q} 22$, and EXOC2/IRF4 near 6p25. These results further establish STAT4 and IRF5 as genetic risk factors for SSc. To verify the novel findings, a case-control set comprising $2,753 \mathrm{SSc}$ patients and 4,569 controls was genotyped for the 3 not previously described variants. Two SNPs identified in the discovery cohort in the EXOC2/IRF4 and CDH7 regions were not replicated in the validation cohort. However, the initial association with rs2056626 in the $C D 247$ gene was replicated [47•]. CD247 is of particular interest considering it has an important role in the immune system by encoding the T-cell receptor zeta subunit, which is a component of the T-cell receptor complex; this gene has also been associated with susceptibility to SLE previously [48]. The association of $C D 247$ was recently replicated independently in a French Caucasian population consisting of $1,031 \mathrm{SSc}$ patients and 1,014 healthy controls [49].

A follow-up study exploiting the above-mentioned GWAS data focused on determining genetic components contributing to $\mathrm{lcSSc}$, dcSSc, ACA positivity, and ATA positivity. To this purpose, a meta-analysis was conducted in 4 cohorts comprising 2,296 SSc patients and 5,171 healthy controls. Subsequently, 18 polymorphisms with a $P$ value lower than $1 \times 10^{-5}-7$ in the lcSSc subtype, 5 in the dcSSc subtype, 2 in ACA positives, and 4 in ATA positives-were further tested in 9 independent cohorts made up of an additional 3,175 SSc patients and 4,971 controls. Overall analysis revealed one variant in the interferon regulatory factor 8 (IRF8) gene (rs11642873) to be associated with $\mathrm{lcSSc}$ at genome-wide significance. Variants in the growth factor receptor-bound protein 10 (GRB10) and sex determining region Y-box 5 (SOX5) were just below the genome-wide significance threshold associated with $1 \mathrm{cSSc}$ and ACA-positive subgroups, respectively (Table 1). Intriguingly, the authors proposed a model of IRF8 and SOX5 affecting the formation of extracellular matrix through collagen, type II, $\alpha 1$ in the skin and other organs of SSc patients. Furthermore, this study revealed genome-wide significant results in the $H L A-D Q B 1$ locus with ACA-positive (OR, 2.48), in the $H L A-D P A 1 / B 1$ loci with ATA-positive (OR, 8.84), and in NOTCH4 with ACA-positive (OR, 0.55) and ATApositive (OR, 0.54). This study is of particular interest because it indicates that the heterogeneity of SSc phenotypes is likely to be the reflection of a different genetic foundation $[50 \bullet$.

Very recently, the fourth GWAS was published that used a high-resolution marker set comparable to that of the previous study ( $\sim 500,000$ markers). The study used a twostep approach; the first step consisted of a GWAS and was conducted in a French cohort consisting of 564 cases and 1,776 controls. Although only 1 SNP showed genome-wide significance, again in the $H L A^{*} D Q B 1$ region, the authors validated 20 SNPs (the top 17 significant SNPs and 3 previously associated SNPs) in a replication cohort of 1,682 SSc cases and 3,926 controls. Follow-up of the top 17 SNPs revealed associations at PSORS1C1 (HLA region), $T N I P 1$, and ras homolog gene family, member B (RHOB) loci (Table 1). Furthermore, the associations of previously identified candidate loci STAT4, IRF5, and CD247 were substantiated. This study also addressed the functional relevance of the findings by investigating the TNIP1 gene and protein expression. TNIP1 was expressed at a lower level in both SSc lesional skin tissue and cultured dermal fibroblasts from SSc patients based on genotype. Intriguingly, TNIP1 showed in vitro inhibitory effects on cytokineinduced collagen production. Although this study presents 
novel and interesting candidate loci, it must be noted that only one locus reached genome-wide significance initially. The other loci became highly significant after pooling of the first and second step but are, strictly speaking, not significant yet in the initial French GWAS. These loci not being identified from the first step may be a power problem resulting from the relatively low number of patients included in the genome-wide association step. In addition, the study does not indicate if there is an overlap between cohorts used for previous studies identifying SSc susceptibility genes STAT4, IRF5, and $C D 247$ and the ones used in this study for replication, which would be welcome in order to place these results in the correct perspective [51].

\section{Gene-Gene Interaction Studies}

As discussed in the previous sections, a large number of genetic variants seem to be involved in SSc susceptibility and pathogenesis. These associated genes all have a very modest but reproducible effect on susceptibility throughout populations. In line with the paradigm of multifactorial diseases, one would expect to be at higher risk of SSc when harboring more susceptibility variants. Not until recently did genetic research in the field of SSc start to combine genetic data to determine whether some variants together formed an additive risk for SSc susceptibility. An additional thought that justifies these attempts is that many SSc candidate genes map to the same biological pathways [5].

The first successful attempt showed that STAT4 (rs7574865) and IRF5 (rs2004640) variants form an additive risk for development of SSc and interstitial lung disease [15]. After this first study, this research group repeated the analysis including the BANK1 polymorphisms and was able to display an additive effect with regard to diffuse SSc susceptibility [52]. In a subsequent analysis, they added an NLRP1 polymorphism to the list of variants interacting with STAT4 and IRF5 [34]. In contrast, the SScassociated $B L K$ region had an additive effect with $B A N K 1$ in the dcSSc subset [53]. An American study showed that the STAT4 polymorphism was predominantly enriched in SSc patients who carried the CC genotype at TBX21 rs 11650354 [16]. Next to this, an interesting study was published in 2010 describing a three-factor model comprising two SNPs: $I L-6-174 C>G$ and the $I L-2-330 G>T$, and the $H L A-B^{*} 3501$ allele that was predictive of the occurrence of digital ulcers in 200 Italian SSc patients [54•].

These initial studies on interactions of susceptibility genes look promising, but they still display only a small proportion of the risk of development of SSc. The most promising findings of gene-gene interactions playing a role likely will come forward from genome-wide interaction analysis. However, this kind of analysis is currently hampered by a lack of computational power and robust statistical methods.

\section{Conclusions}

This review aimed to provide an overview of the genetic research that has been conducted in the field of SSc in the past year. When reviewing this research, it becomes apparent that exciting progress has been made in several aspects of genetic research, including family-based studies, candidate studies, and (most noteworthy) GWAS. These observations together further substantiate the role of genetic susceptibility in SSc.

Although association studies of SSc in previous years mainly addressed genetic variants emerging from observations in other AIDs, last year, investigators turned with an increasing frequency toward genes involved in distinct biological processes by function that were possibly involved in SSc pathogenesis. This, however, yielded positive and negative results, with on one hand associations of NLRP1 and KCNA5 with PAH, and on the other hand no associations with fibrosis-related $M M P$ genes. An attractive future perspective is the increasing number of multicenter initiatives focusing on unraveling the genetic background of SSc. This has the potential to lead to large genetic consortia with more than 10,000 SSc DNA samples, wellpowered to discover even smaller genetic effects. The single most important step forward is the large and robust

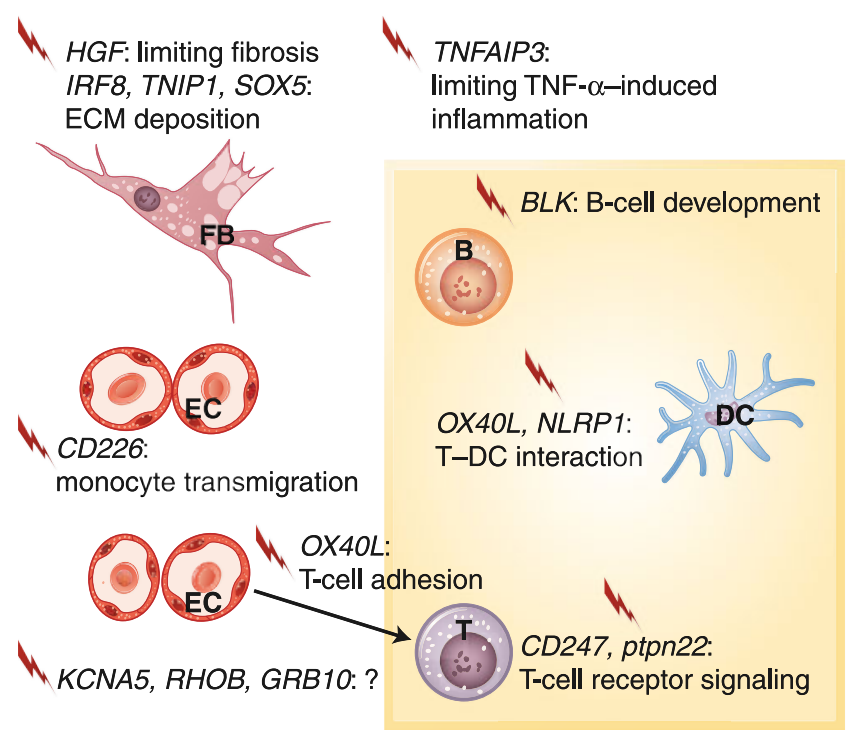

Fig. 1 Graphical representation of the immunologic point of impact of the newly discovered systemic sclerosis susceptibility genes. B-B cell; DC — dendritic cell; EC — vascular endothelial cell; ECM — extracellular matrix; FB - fibroblast; T-T cell; TNF-tumor necrosis factor 
GWAS published last year; this study identified susceptibility genes similar to other AIDs, including RA and SLE. The challenge for the following years will be to identify whether certain combinations of risk alleles can drive the development of a particular AID, such as SSc, on a genetically similar background. In parallel with this, epigenetic research should focus on investigating the connections between the genetically susceptible host and the impact of environmental factors on expression of this susceptible genotype. The observation that birth order is a risk factor for SSc, reported last year, strongly hints in this direction.

An important gap in our understanding of the genetics involved in $\mathrm{SSc}$ is the lack of functional validation of genetic findings in immune cells or fibroblasts. Fortunately, this is being addressed more and more. Adding this functional validation step to candidate gene studies has become more mainstream in the past year, which enables researchers dedicated to investigating SSc pathogenesis on a cellular level to pick interesting molecules more efficiently from genetics research. This is of particular interest because the newly discovered variants affect multiple immunologic processes (Fig. 1). Another point, well-recognized as problematic in genetic research, is the translation from bench to bedside or, more precisely, the relevant clinical consequences of carrying a genetic variant that increases the risk of developing SSc. This is slowly becoming more apparent to researchers in the realm of SSc genetic research, as complication risk analysis using follow-up data is published at an increased rate. Ultimately, genetic risk factors might be used to better predict the development of scleroderma renal crisis, pulmonary hypertension, and pulmonary fibrosis. This might enable rheumatologists and other physicians to identify patients at risk early and start preventive treatment or check-ups at a higher frequency. A problematic subject in this aspect remains the low OR reported for genetic variants associated with complication development. However, if the investigations into applicable gene-gene interactions continue to expand in the way they did last year, combinations of polymorphisms might be discovered that provide enough risk to become clinical relevant for testing and a prelude to preventive treatments in the upcoming years.

In summary, there has been a steep increase in knowledge regarding the genetic background of SSc in the past year. This knowledge together with previous investigations forms a solid base for the next and most important step: the translation of genetic findings to more efficient patient care and therapeutic interventions.

Disclosure No potential conflicts of interest relevant to this article were reported.
Open Access This article is distributed under the terms of the Creative Commons Attribution Noncommercial License which permits any noncommercial use, distribution, and reproduction in any medium, provided the original author(s) and source are credited.

\section{References}

Papers of particular interest, published recently, have been highlighted as:

- Of importance

1. Varga J, Abraham D. Systemic sclerosis: a prototypic multisystem fibrotic disorder. J Clin Invest. 2007;117(3):557-67.

2. Ranque B, Mouthon L. Geoepidemiology of systemic sclerosis. Autoimmun Rev. 2010;9(5):A311-8. Epub 2009 Nov 10.

3. Agarwal SK. The genetics of systemic sclerosis. Discov Med. 2010;10(51):134-43.

4. McCormic ZD, Khuder SS, Aryal BK, Ames AL, Khuder SA. Occupational silica exposure as a risk factor for scleroderma: a meta-analysis. Int Arch Occup Environ Health. 2010;83(7):763-9. Epub 2010 Jan 3.

5. Broen JCA, Coenen MJH, Radstake TRDJ. Deciphering the genetic background of systemic sclerosis. Expert Rev Clin Immunol. 2011.

6. Englert H, Small-McMahon J, Chambers P, O'Connor H, Davis K, Manolios N, White R, Dracos G, Brooks P. Familial risk estimation in systemic sclerosis. Aust N Z J Med. 1999;29(1):3641.

7. Arnett FC, Cho M, Chatterjee S, Aguilar MB, Reveille JD, Mayes MD. Familial occurrence frequencies and relative risks for systemic sclerosis (scleroderma) in three United States cohorts. Arthritis Rheum. 2001;44(6):1359-62.

8. Frech T, Khanna D, Markewitz B, Mineau G, Pimentel R, Sawitzke A. Heritability of vasculopathy, autoimmune disease, and fibrosis in systemic sclerosis: a population-based study. Arthritis Rheum. 2010;62(7):2109-16.

9. Arora-Singh RK, Assassi S, del Junco DJ, Arnett FC, Perry M, Irfan U, Sharif R, Mattar T, Mayes MD. Autoimmune diseases and autoantibodies in the first degree relatives of patients with systemic sclerosis. J Autoimmun. 2010;35(1):52-7. Epub 2010 Mar 11.

10. - Cockrill T, del Junco DJ, Arnett FC, Assassi S, Tan FK, McNearney T, Fischbach M, Perry M, Mayes MD. Separate influences of birth order and gravidity/parity on the development of systemic sclerosis. Arthritis Care Res (Hoboken). 2010 Mar;62 (3):418-24. This study is interesting because it points to the existence of mechanisms involved in determining SSc susceptibility during embryonic development or birth.

11. Jimenez SA, Artlett CM. Microchimerism and systemic sclerosis. Curr Opin Rheumatol. 2005;17(1):86-90.

12. Remmers EF, Plenge RM, Lee AT, Graham RR, Hom G, Behrens TW, de Bakker PI, Le JM, Lee HS, Batliwalla F, Li W, Masters SL, Booty MG, Carulli JP, Padyukov L, Alfredsson L, Klareskog L, Chen WV, Amos CI, Criswell LA, Seldin MF, Kastner DL, Gregersen PK. STAT4 and the risk of rheumatoid arthritis and systemic lupus erythematosus. N Engl J Med. 2007;357(10):97786.

13. Rueda B, Broen J, Simeon C, Hesselstrand R, Diaz B, Suárez H, Ortego-Centeno N, Riemekasten G, Fonollosa V, Vonk MC, van den Hoogen FH, Sanchez-Román J, Aguirre-Zamorano MA, García-Portales R, Pros A, Camps MT, Gonzalez-Gay MA, Coenen MJ, Airo P, Beretta L, Scorza R, van Laar J, GonzalezEscribano MF, Nelson JL, Radstake TR, Martin J. The STAT4 
gene influences the genetic predisposition to systemic sclerosis phenotype. Hum Mol Genet. 2009;18(11):2071-7. Epub 2009 Mar 13.

14. Tsuchiya N, Kawasaki A, Hasegawa M, Fujimoto M, Takehara K, Kawaguchi Y, Kawamoto M, Hara M, Sato S. Association of STAT4 polymorphism with systemic sclerosis in a Japanese population. Ann Rheum Dis. 2009;68(8):1375-6.

15. Dieudé P, Guedj M, Wipff J, Ruiz B, Hachulla E, Diot E, Granel B, Sibilia J, Tiev K, Mouthon L, Cracowski JL, Carpentier PH, Amoura Z, Fajardy I, Avouac J, Meyer O, Kahan A, Boileau C, Allanore Y. STAT4 is a genetic risk factor for systemic sclerosis having additive effects with IRF5 on disease susceptibility and related pulmonary fibrosis. Arthritis Rheum. 2009;60(8):2472-9.

16. Gourh P, Agarwal SK, Divecha D, Assassi S, Paz G, Arora-Singh RK, Reveille JD, Shete S, Mayes MD, Arnett FC, Tan FK. Polymorphisms in TBX21 and STAT4 increase the risk of systemic sclerosis: evidence of possible gene-gene interaction and alterations in Th1/Th2 cytokines. Arthritis Rheum. 2009;60 (12):3794-806.

17. • Avouac J, Fürnrohr BG, Tomcik M, Palumbo K, Zerr P, Horn A, Dees C, Akhmetshina A, Beyer C, Distler O, Schett G, Allanore Y, Distler JH. Inactivation of the transcription factor STAT4 prevents inflammation-driven fibrosis in systemic sclerosis animal models. Arthritis Rheum. 2010 Nov 30. [Epub ahead of print]. This was an interesting study as it investigated for the first time a gene strongly implicated in SSc susceptibility, STAT4, in a murine model of SSc.

18. Redmond WL, Ruby CE, Weinberg AD. The role of OX40mediated co-stimulation in T-cell activation and survival. Crit Rev Immunol. 2009;29(3):187-201.

19. Gourh P, Arnett FC, Tan FK, Assassi S, Divecha D, Paz G, McNearney T, Draeger H, Reveille JD, Mayes MD, Agarwal SK. Association of TNFSF4 (OX40L) polymorphisms with susceptibility to systemic sclerosis. Ann Rheum Dis. 2010;69(3):550-5. Epub 2009 Sep 23.

20. Bossini-Castillo L, Broen JC, Simeon CP, Beretta L, Vonk MC, Ortego-Centeno N, Espinosa G, Carreira P, Camps MT, Navarrete N, González-Escribano MF, Vicente-Rabaneda E, Rodríguez L, Tolosa C, Román-Ivorra JA, Gómez-Gracia I, García-Hernández FJ, Castellví I, Gallego M, Fernández-Nebro A, García-Portales R, Egurbide MV, Fonollosa V, de la Peña PG, Pros A, GonzálezGay MA, Hesselstrand R, Riemekasten G, Witte T, Coenen MJ, Koeleman BP, Houssiau F, Smith V, de Keyser F, Westhovens R, De Langhe E, Voskuyl AE, Schuerwegh AJ, Chee MM, Madhok R, Shiels P, Fonseca C, Denton C, Claes K, Padykov L, Nordin A, Palm O, Lie BA, Airó P, Scorza R, van Laar JM, Hunzelmann N, Kreuter A, Herrick A, Worthington J, Radstake TR, Martín J, Rueda B. A replication study confirms the association of TNFSF4 (OX40L) polymorphisms with systemic sclerosis in a large European cohort. Ann Rheum Dis. 2010 Dec 27. [Epub ahead of print].

21. Orozco G, Eyre S, Hinks A, Bowes J, Morgan AW, Wilson AG, Wordsworth P, Steer S, Hocking L, UKRAG consortium, Thomson W, Worthington J, Barton A. Study of the common genetic background for rheumatoid arthritis and systemic lupus erythematosus. Ann Rheum Dis. 2011;70(3):463-8. Epub 2010 Nov 10.

22. Gourh P, Agarwal SK, Martin E, Divecha D, Rueda B, Bunting H, Assassi S, Paz G, Shete S, McNearney T, Draeger H, Reveille JD, Radstake TR, Simeon CP, Rodriguez L, Vicente E, Gonzalez-Gay MA, Mayes MD, Tan FK, Martin J, Arnett FC. Association of the C8orf13-BLK region with systemic sclerosis in North-American and European populations. J Autoimmun. 2010;34(2):155-62. Epub 2009 Sep 30.

23. Ito I, Kawaguchi Y, Kawasaki A, Hasegawa M, Ohashi J, Kawamoto M, Fujimoto M, Takehara K, Sato S, Hara M,
Tsuchiya N. Association of the FAM167A-BLK region with systemic sclerosis. Arthritis Rheum. 2010;62(3):890-5.

24. Musone SL, Taylor KE, Nititham J, Chu C, Poon A, Liao W, Lam ET, Ma A, Kwok PY, Criswell LA. Sequencing of TNFAIP3 and association of variants with multiple autoimmune diseases. Genes Immun. 2011;12(3):176-82. Epub 2011 Feb 17.

25. Dieudé P, Guedj M, Wipff J, Ruiz B, Riemekasten G, MatucciCerinic M, Melchers I, Hachulla E, Airo P, Diot E, Hunzelmann N, Cabane J, Mouthon L, Cracowski JL, Riccieri V, Distler J, Meyer O, Kahan A, Boileau C, Allanore Y. Association of the TNFAIP3 rs5029939 variant with systemic sclerosis in the European Caucasian population. Ann Rheum Dis. 2010;69 (11):1958-64. Epub 2010 May 28.

26. Remillard CV, Tigno DD, Platoshyn O, Burg ED, Brevnova EE, Conger D, Nicholson A, Rana BK, Channick RN, Rubin LJ, O'Connor DT, Yuan JX. Function of Kv1.5 channels and genetic variations of KCNA5 in patients with idiopathic pulmonary arterial hypertension. Am J Physiol Cell Physiol. 2007;292(5): C1837-53. Epub 2007 Jan 31.

27. Wipff J, Dieudé P, Guedj M, Ruiz B, Riemekasten G, Cracowski JL, Matucci-Cerinic M, Melchers I, Humbert M, Hachulla E, Airo P, Diot E, Hunzelmann N, Caramaschi P, Sibilia J, Valentini G, Tiev K, Girerd B, Mouthon L, Riccieri V, Carpentier PH, Distler J, Amoura Z, Tarner I, Degano B, Avouac J, Meyer O, Kahan A, Boileau C, Allanore Y. Association of a KCNA5 gene polymorphism with systemic sclerosis-associated pulmonary arterial hypertension in the European Caucasian population. Arthritis Rheum. 2010;62(10):3093-100.

28. Burn GL, Svensson L, Sanchez-Blanco C, Saini M, Cope AP. Why is PTPN22 a good candidate susceptibility gene for autoimmune disease? FEBS Lett. 2011 Apr 20. [Epub ahead of print].

29. Dieudé P, Guedj M, Wipff J, Avouac J, Hachulla E, Diot E, Granel B, Sibilia J, Cabane J, Meyer O, Mouthon L, Kahan A, Boileau C, Allanore Y. The PTPN22 620W allele confers susceptibility to systemic sclerosis: findings of a large case-control study of European Caucasians and a meta-analysis. Arthritis Rheum. 2008;58(7):2183-8.

30. Balada E, Simeón-Aznar CP, Serrano-Acedo S, Martínez-Lostao L, Selva-O'Callaghan A, Fonollosa-Pla V, Vilardell-Tarrés M. Lack of association of the PTPN22 gene polymorphism R620W with systemic sclerosis. Clin Exp Rheumatol. 2006;24(3):321-4.

31. Gourh P, Tan FK, Assassi S, Ahn CW, McNearney TA, Fischbach M, Arnett FC, Mayes MD. Association of the PTPN22 R620W polymorphism with anti-topoisomerase I- and anticentromere antibody-positive systemic sclerosis. Arthritis Rheum. 2006;54 (12):3945-53.

32. Diaz-Gallo LM, Gourh P, Broen J, Simeon C, Fonollosa V, Ortego-Centeno N, Agarwal S, Vonk MC, Coenen M, Riemekasten G, Hunzelmann N, Hesselstrand R, Tan FK, Reveille JD, Assassi S, García-Hernandez FJ, Carreira P, Camps MT, Fernandez-Nebro A, de la Peña PG, Nearney T, Hilda D, González-Gay MA, Airo P, Beretta L, Scorza R, Herrick A, Worthington J, Pros A, GómezGracia I, Trapiella L, Espinosa G, Castellvi I, Witte T, de Keyser F, Vanthuyne M, Mayes MD, Radstake TR, Arnett FC, Martin J, Rueda B. Analysis of the influence of PTPN22 gene polymorphisms in systemic sclerosis. Ann Rheum Dis. 2011;70(3):454-62. Epub 2010 Dec 3.

33. Guarda G, Dostert C, Staehli F, Cabalzar K, Castillo R, Tardivel A, Schneider P, Tschopp J. T cells dampen innate immune responses through inhibition of NLRP1 and NLRP3 inflammasomes. Nature. 2009;460(7252):269-73. Epub 2009 Jun 3.

34. Dieudé P, Guedj M, Wipff J, Ruiz B, Riemekasten G, Airo P, Melchers I, Hachulla E, Cerinic MM, Diot E, Hunzelmann N, Caramaschi P, Sibilia J, Tiev K, Mouthon L, Riccieri V, Cracowski JL, Carpentier PH, Distler J, Amoura Z, Tarner I, 
Avouac J, Meyer O, Kahan A, Boileau C, Allanore Y. NLRP1 influences the systemic sclerosis phenotype: a new clue for the contribution of innate immunity in systemic sclerosis-related fibrosing alveolitis pathogenesis. Ann Rheum Dis. 2010 Dec 13. [Epub ahead of print].

35. Mizuno S, Matsumoto K, Nakamura T. HGF as a renotrophic and anti-fibrotic regulator in chronic renal disease. Front Biosci. 2008;13:7072-86.

36. - Hoshino K, Satoh T, Kawaguchi Y, Kuwana M. Hepatocyte growth factor promoter polymorphism is associated with severity of interstitial lung disease in Japanese patients with systemic sclerosis. Arthritis Rheum. 2011 Apr 22. doi: 10.1002/art.30415. [Epub ahead of print]. The authors of this study investigated a functional gene in fibrosis in a clear matter, using follow-up data to present the information in a clinically relevant way.

37. Reymond N, Imbert AM, Devilard E, Fabre S, Chabannon C, Xerri L, Farnarier C, Cantoni C, Bottino C, Moretta A, Dubreuil P, Lopez M. DNAM-1 and PVR regulate monocyte migration through endothelial junctions. J Exp Med. 2004;199(10):133141. Epub 2004 May 10.

38. Maiti AK, Kim-Howard X, Viswanathan P, Guillén L, Qian X, Rojas-Villarraga A, Sun C, Cañas C, Tobón GJ, Matsuda K, Shen $\mathrm{N}$, Cherñavsky AC, Anaya JM, Nath SK. Non-synonymous variant (Gly307Ser) in CD226 is associated with susceptibility to multiple autoimmune diseases. Rheumatology (Oxford). 2010;49(7):1239-44. Epub 2010 Mar 24.

39. Dieudé P, Guedj M, Truchetet ME, Wipff J, Revillod L, Riemekasten G, Matucci-Cerinic M, Melchers I, Hachulla E, Airo P, Diot E, Hunzelmann N, Mouthon L, Cabane J, Cracowski JL, Riccieri V, Distler J, Amoura Z, Valentini G, Camaraschi P, Tarner I, Frances C, Carpentier P, Brembilla NC, Meyer O, Kahan A, Chizzolini C, Boileau C, Allanore Y. Association of the CD226 Ser(307) variant with systemic sclerosis: evidence of a contribution of costimulation pathways in systemic sclerosis pathogenesis. Arthritis Rheum. 2011;63(4):1097-105. doi:10.1002/art.30204.

40. Alizadeh BZ, Broen J, Rueda B, Hesselstrand R, Wuttge D, Simeon C, Ortego-Centeno N, Gonzalez-Gay MA, Pros A, Herrick A, Worthington J, Denton C, Fonseca C, Riemekasten G, Vonk MC, van den Hoogen F, Guiducci S, Matucci-Cerinic M, Scorza R, Beretta L, Airó P, Coenen M, Martin J, Koeleman BP, Radstake TR, EUSTAR. Functional variants of Fc gamma receptor (FCGR2A) and FCGR3A are not associated with susceptibility to systemic sclerosis in a large European Study (EUSTAR). J Rheumatol. 2010;37(8):1673-9. Epub 2010 Jun 15.

41. Coustet B, Agarwal SK, Gourh P, Guedj M, Mayes MD, Dieude P, Wipff J, Avouac J, Hachulla E, Diot E, Cracowski JL, Tiev K, Sibilia J, Mouthon L, Frances C, Amoura Z, Carpentier P, Meyer O, Kahan A, Boileau C, Arnett FC, Allanore Y. Association study of ITGAM, ITGAX, and CD58 autoimmune risk loci in systemic sclerosis: results from 2 large European Caucasian cohorts. J Rheumatol. 2011 Mar 1. [Epub ahead of print].

42. Broen JC, Coenen MJ, Rueda B, Witte T, Padyukov L, Klareskog L, Hesselstrand R, Wuttge DM, Simeon C, Ortego-Centeno N, González-Gay MA, Pros A, Hunzelman N, Riemekasten G, Kreuter A, Vonk M, Scorza R, Beretta L, Airò P, van Riel PL, Kimberly R, Martin J, Edberg J, Radstake TR. The functional polymorphism $844 \mathrm{~A}>\mathrm{G}$ in $\mathrm{Fc} \alpha \mathrm{RI}$ (CD89) does not contribute to systemic sclerosis or rheumatoid arthritis susceptibility. J Rheumatol. 2011;38(3):446-9. Epub 2010 Dec 15.

43. Wipff J, Bonnet P, Ruiz B, Dieude P, Avouac J, Tiev K, Hachulla E, Cracowski JL, Diot E, Sibilia J, Mouthon L, Meyer O, Kahan A, Boileau C, Allanore Y. Association study of serotonin transporter gene (SLC6A4) in systemic sclerosis in European Caucasian populations. J Rheumatol. 2010;37(6):1164-7. Epub 2010 Apr 15.
44. Wipff J, Dieude P, Avouac J, Tiev K, Hachulla E, Cracowski JL, Diot E, Sibilia J, Mouthon L, Meyer O, Kahan A, Boileau $\mathrm{C}$, Allanore Y. Association of metalloproteinase gene polymorphisms with systemic sclerosis in the European Caucasian population. J Rheumatol. 2010;37(3):599-602. Epub 2010 Jan 28.

45. Zhou X, Tan FK, Wang N, Xiong M, Maghidman S, Reveille JD, Milewicz DM, Chakraborty R, Arnett FC. Genome-wide association study for regions of systemic sclerosis susceptibility in a Choctaw Indian population with high disease prevalence. Arthritis Rheum. 2003;48(9):2585-92.

46. Zhou X, Lee JE, Arnett FC, Xiong M, Park MY, Yoo YK, Shin ES, Reveille JD, Mayes MD, Kim JH, Song R, Choi JY, Park JA, Lee YJ, Lee EY, Song YW, Lee EB. HLA-DPB1 and DPB2 are genetic loci for systemic sclerosis: a genome-wide association study in Koreans with replication in North Americans. Arthritis Rheum. 2009;60(12):3807-14.

47. - Radstake TR, Gorlova O, Rueda B, Martin JE, Alizadeh BZ, Palomino-Morales R, Coenen MJ, Vonk MC, Voskuyl AE, Schuerwegh AJ, Broen JC, van Riel PL, van 't Slot R, Italiaander A, Ophoff RA, Riemekasten G, Hunzelmann N, Simeon CP, Ortego-Centeno N, González-Gay MA, González-Escribano MF; Spanish Scleroderma Group, Airo P, van Laar J, Herrick A, Worthington J, Hesselstrand R, Smith V, de Keyser F, Houssiau F, Chee MM, Madhok R, Shiels P, Westhovens R, Kreuter A, Kiener H, de Baere E, Witte T, Padykov L, Klareskog L, Beretta L, Scorza R, Lie BA, Hoffmann-Vold AM, Carreira P, Varga J, Hinchcliff M, Gregersen PK, Lee AT, Ying J, Han Y, Weng SF, Amos CI, Wigley FM, Hummers L, Nelson JL, Agarwal SK, Assassi S, Gourh P, Tan FK, Koeleman BP, Arnett FC, Martin J, Mayes MD. Genome-wide association study of systemic sclerosis identifies CD247 as a new susceptibility locus. Nat Genet. 2010 May;42(5):426-9. Epub 2010 Apr 11. This study is of particular importance because it investigated the genetic susceptibility to $\mathrm{SSc}$ in a non-hypothesis-driven way, further substantiating a common genetic background for AIDs.

48. Gorman CL, Russell AI, Zhang Z, Cunninghame Graham D, Cope AP, Vyse TJ. Polymorphisms in the CD3Z gene influence TCRzeta expression in systemic lupus erythematosus patients and healthy controls. J Immunol. 2008;180(2):1060-70.

49. Dieudé P, Boileau C, Guedj M, Avouac J, Ruiz B, Hachulla E, Diot E, Cracowski JL, Tiev K, Sibilia J, Mouthon L, Frances C, Amoura Z, Carpentier P, Cosnes A, Meyer O, Kahan A, Chiocchia $\mathrm{G}$, Allanore Y. Independent replication establishes the CD247 gene as a genetic systemic sclerosis susceptibility factor. Ann Rheum Dis. 2011 Apr 7. [Epub ahead of print].

50. - Gorlova O, Martin JE, Rueda B, Koeleman BPC, Ying J, Teruel M, Diaz-Gallo LM, Broen J, Vonk MC, Simeon CP, Alizadeh BZ, Coenen MJH, Voskuyl AE, Schuerwegh AJ, Van Riel PLCM, Vanthuyne M, Van't Slot R, Italiaander, Ophoff RA, Hunzelmann N, Fonollosa V, Ortego-Centeno N, González-Gay MA, GarcíaHernández FJ, González-Escribano MF, Airo' P, Van Laar J, Worthington J, Hesselstrand R, Smith V, De Keyser F, Houssiau F, Chee MM, Madhok R, Shiels P, Westhovens R, Kreuter A, De Baere E, Witte T, Padyukov L, Nordin A, Scorza R, Lunardi C, Lie BA, Hoffmann-Vold AM, De la Peña PG, Carreira P, Varga J, Hinchcliff M, Lee AT, Gourh P, Amos CI, Wigley FM, Hummers LK, Nelson JL, Riemekasten G, Herrick A, Beretta L, Fonseca C, Denton CP, Gregersen PK, Agarwal S, Assassi S, Tan FK, Arnett FC, Radstake TRDJ, Mayes MD, Martin J. Identification of novel genetic markers associated with clinical phenotypes and autoantibody subsets of systemic sclerosis through a genome wide association strategy. PLoS Genet. 2011. This study is of particular interest because it indicates that the heterogeneity of SSc phenotypes is likely to be the reflection of a different genetic foundation. 
51. Allanore Y, Saad M, Dieudé, Avouac J, Distler JHW, Amouye P, Matucci-Cerinic M, Riemekasten G, Airo’ P, Melchers I, Hachulla E, Daniele C, Wichmann HE, Wipff J, Lambert JC, Hunzelmann N, Tiev K, Caramaschi P, Diot E, Kowal-Bielecka O, Valentini G, Mouthon L, Czirják L, Damjanov N, Salvi E, Conti C, Muller M, Muller-Ladner U, Riccieri V, Ruiz B, Cracowski JL, Letenneur L, Dupuy AM, Meyer O, Kahan A, Munnich A, Boileau C, Martinez M. Genomewide scan identifies TNIP1, PSORS1C1 and RHOB as novel risk loci for Systemic Sclerosis. PLoS Genet. 2011.

52. Dieudé P, Wipff J, Guedj M, Ruiz B, Melchers I, Hachulla E, Riemekasten G, Diot E, Hunzelmann N, Sibilia J, Tiev K, Mouthon L, Cracowski JL, Carpentier PH, Distler J, Amoura Z, Tarner I, Avouac J, Meyer O, Kahan A, Boileau C, Allanore Y. BANK1 is a genetic risk factor for diffuse cutaneous systemic sclerosis and has additive effects with IRF5 and STAT4. Arthritis Rheum. 2009;60(11):3447-54.
53. Coustet B, Dieudé P, Guedj M, Bouaziz M, Avouac J, Ruiz B, Hachulla E, Diot E, Kracowski JL, Tiev K, Sibilia J, Mouthon L, Frances C, Amoura Z, Carpentier P, Cosnes A, Meyer O, Kahan A, Boileau C, Chiocchia G, Allanore Y. C8orf 13/BLK is a genetic risk locus for systemic sclerosis and has additive effect with BANK1: results from a large French cohort and metaanalysis. Arthritis Rheum. 2011. doi:10.1002/art.30379 [Epub ahead of print].

54. - Beretta L, Santaniello A, Mayo M, Cappiello F, Marchini M, Scorza R. A 3-factor epistatic model predicts digital ulcers in Italian scleroderma patients. Eur J Intern Med. 2010 Aug;21 (4):347-53. Epub 2010 Jun 23. This study may be a prelude to a method investigating the additive effects of multiple polymorphisms on SSc complication development; it also shows that these genetic models do not necessarily need to consist of previously associated genes. 